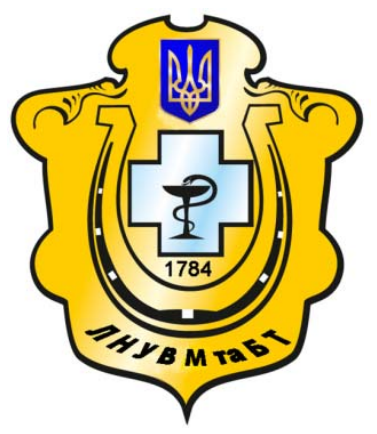

Науковий вісник Львівського національного університету ветеринарної медицини та біотехнологій імені С.3. Гжицького

Scientific Messenger of Lviv National University of Veterinary Medicine and Biotechnologies named after S.Z. Gzhytskyj

doi:10.15421/nvlvet7115

ISSN 2413-5550 print

ISSN 2518-1327 online

$\underline{\text { http://nvlvet.com.ua/ }}$

UDC 619:578(075.8)

\title{
Clinical signs in diagnostic of circovirus infection in pigs
}

\author{
O. Novitska \\ novi_o@ukr.net \\ National University of life and environmental sciences of Ukraine, \\ Heroyiv Oborony Str., 11, Kyiv, 03041, Ukraine
}

\begin{abstract}
Clinical signs the disease associated with porcine circovirus (PCVAD) imitate many other diseases (classical swine fever, transmissible gastroenteritis, porcine parvovirus, pseudo rabies (Aujeszky's disease), leptospirosis et al.), which complicates diagnosis of the disease in the early stages of infection among livestock. Late diagnosis, lack of treatment and high price vaccines contribute to the formation of stationary fire PCVD. Therefore, the preliminary diagnosis based on clinical signs and pathological changes in animals suffering from PCV2, is the primary in fight PCVD. According the notification of clinical and pathological signs PCVD we examined the number of pigs on the farm that specializes in young animals received and fattening. Farms specialists concerned about the low increase of body weight, but they did not think of circovirus infection of pigs. We divided all pigs in to three groups. The first group - adult sows, the second group - pigs 0 - 28 days old, the third group - pigs between 35 - 180 days old. All animals were clinically examined. Animals of the first group did not have clinical signs specific to PCVD. Animals of the second group were characterized with heterogeneity of group, weight of piglets at birth ranged from 0.9 to $1.3 \mathrm{~kg}$. Animals were behind in growth, development, mortality ranged from 10\%. Diarrhea and cough were not detected. The third group of animals was characterized with strong heterogeneity of herds and low growth. Testing revealed a lag in growth and development, depression, palemucous membranes, increasing the inguinal, submaxillary, retropharyngeal lymphnodes. Autopsy revealed: fibrinous pleuropneumonia, myocarditis, filling with blood of spleen and liver, enlarged kidneys, increased all the lymph nodes, especially in guinal and ripples. Signs of generalized staph infection were recorded with one pig. Using PCR analysis confirmed PCV2.
\end{abstract}

Key words: circovirus, PCV2, PCVD, PCVAD, pigs, clinical signs

\section{Значення клінічних ознак у системі діагностування цирковірозу свиней}

\author{
О. Новіцька \\ novi_o@ukr.net \\ Національний університет біоресурсів і природокористування Украӥни, \\ вул. Героїв Оборони, 11, м. Київ, 03041, Украӥна
}

Клінічні ознаки асоиійованої цирковірусної інфекиії свиней (PCVAD) імітують багато інших захворювань (класична чума свиней, трансмісивний гастроентерит, хвороба Ауєскі, парвовірусна інфекиія та ін.), щзо ускладнює діагностування хвороби на початкових етапах розвитку інфекції серед поголів'я. Пізня діагностика, відсутність засобів лікування та висока ціна вакиини сприяють утворенню стаціонарного вогнища PCVD. Тому, попередній діагноз на підставі клінічних ознак та патологоанатомічних змін тварин, хворих на PCV2, є першочерговим у системі боротьби з PCVD та асоиійованими хворобами. Нами було обстежено поголів'я свиней на фермі повного ијику отримання продукиії свинарства. Основними клінічними ознаками були низькі прирости маси тіла. Усе поголів'я свиней було умовно поділено на три групи. Перша група - дорослі свиноматки, друга група - свині віком 0 - 28 діб, третя група - свині віком від 35 - 180 діб. Обстеження тварин першої групи не виявило клінічних ознак характерних для PCVD. Тварини другої групи характеризувалися неоднорідністю гнізда, маса тіла поросят при народженні коливалася від 0,9 до 1,3 кг. Тварини відставали у рості, розвитку, смертність коливалась у межах 10\%. Проносу та кашлю не виявляли. Третя група тварин характеризувалася сильною неоднорідністю стада та низьким приростом маси тіла. Обстеження тварин виявило відставання у рості та розвитку,

Citation:

Novitska, O. (2016). Clinical signs in diagnostic of circovirus infection in pigs. Scientific Messenger LNUVMBT named after S.Z. Gzhytskyj, 18, 3(71), 66-69. 
пригніченість, блідість слизових, збільшення пахових, підмелепових, заглоткових лімфатичних вузлів. Патологоанатомічними дослідженнями виявили: фібринозну плевропневмонію, міокардит, кровонаповнення селезінки та печінки, збільшені нирки, збільшені усі лімфатичні вузли, особливо пахові та брижові. У одного поросяти також реєстрували ознаки генералізованої стафілококової інфекиії. У досліджуваному патологічному матеріалі за допомогою ПлР- аналізу було підтверджено наявність РCV2.

Ключові слова: цуирковірус, PCV2, PCVD, PCVAD, свині, клінічні ознаки.

\title{
Значение клинических признаков для диагностики цирковирусной инфекции свиней
}

\author{
О. Новицкая \\ novi_o@ukr.net \\ Наџиональный университет биоресурсов и природопользования Украинь,, \\ ул. Героев Обороны, 11, Киев, 03041, Украина
}

\begin{abstract}
Клинические признаки ассочиированной иирковирусной инфекции свиней (PCVAD) имитируют ряд других заболеваний (классическая чума свиней, трансмиссивный гастроэнтерит свиней, болезнь Ауэски, парвовирусная инфекция и др.), что затрудняет диагностирование болезни на ранних этапах развития болезни среди поголовья. Поздняя диагностика, отсутствие средств лечения и высокая иена вакиин благоприятствуют образованию стационарного очага PCVD. Поэтому, предварительный диагноз на основе клинических и патологоанатомических признаков животных, больных на РCV2, являются первоочередными в системе борьбы с РCVD. Нами было исследовано поголовье свиней на ферме полного иикла получения продукиии свиноводства. Основными клиническими признаками были низкие приросты массы тела. Всё поголовье свиней было условно поделено на три группы. Первая группа - взрослые свиноматки, вторая группа - свиньи возрастом 0 28 дней, третья группа - свиньи возрастом 35 - 180 дней. Исследование животных первой группь не выявило клинических признаков характерных для РCVD. Животные второй группы характеризовались неоднородностью гнезда, масса тела поросят при рождении колебалась от 0,9 до 1,3 кг. Животные отставали в росте, развитии, смертность было в пределах 10\%. Поносов и кашлю не выявляли. Третья группа животных характеризовалась сильной неоднородностью стада и низкими приростами массы тела. Исследования вывили угнетенность, бледность слизистых, увеличение паховых, подчелюстных лимфатических узлов. Патологоанатомическими исследованиями выявляли фибринозную плевропневмонию, миокардит, кровенаполнение селезёнки и печени, увеличение почек и всех лимфатических узлов, особенно паховых и брыжовых. У одного поросёнка регистрировали признаки генерализованой стафилококковой инфекции. В исследуемом материале $c$ помощью ПЦР-анализу было подтверждено наличие РCV2.
\end{abstract}

Ключевые слова: ичирковирус, PCV2, PCVD, PCVAD, свиньи, клинические признаки.

\section{Introduction}

Porcine circovirus is obe of the most studied pathogens among those that are the most actual during the last 15 years. However, in Ukraine the disease associated with porcine circovirus (PCVAD) become signs of a pandemic. Detection of specific antibodies in the blood serum of pigs shows that circovirus infection of pigs (PCVD) is widespread in the world, regardless of the status of PCV2 farms (Segalés et al., 2005).

Efficiency of histological, immunohistochemical and PCR methods for the diagnosis of circovirus infection in pigs has been proven many times. However, clinical signs PCVAD imitate many ot her diseases (classical swine fever, transmissible gastroenteritis, porcine parvovirus, pseudorabies (Aujeszky disease), leptospirosis et al.), which complicates diagnosis of the disease in the early stages of infection among livestock (Kim et al., 2004; Opriessnig and Langohr, 2013).

If experts of a farm think there is no presence PCV2, they will not do additional diagnostic tests. Typically, diagnosis PCVAD occurs when the infection has become total, chronic course. Late diagnosis, lack of treatment and high price vaccines contribute to the formation of stationary fire PCVD. Therefore, the preliminary diagnosis based on clinical signs and pathological changes in animals suffering from PCV2, is the primary in fight PCVD PCVAD.
PCV2 causes the development of immunodeficiency, so animals are usually infected by several agents, including parvovirus pigs, swine reproductive and respiratory syndrome virus, Swine Hepatitis E virus, Mycoplasma hyopneumoniae, Actinobacillus pleuropneumoniae, Pasteurella multocida, Haemophilus parasuis, Staphilococcus spp., Streptococcus spp. (Yang et al., 2015). The most studied is the association of swine circovirus virus reproductive and respiratory syndrome pigs and porcine parvovirus (Madson and Opriessnig, 2011).

The main targets for PCV2 in the neonatal period are cardiomyocytes, hepatocytes and macrophages. In postnatal virus replicates well in the cells of the lymphatic system, heart, lungs, liver, spleen, kidneys and brain (Romeo et al., 2003). So symptoms of circovirus infection of pigs vary on clinical grounds. For postweaning multisystemic wasting syndrome - PMWS (PCV2-SD) characteristic is the development of acquired immunodeficiency (Ellis et al., 1998; Quintana et al., 2001). This syndrome occurs most frequently. Lymphocyte depletion of lymphoid tissue, changes subpopulations in peripheral blood mononuclear cells, expression changes of cytokines are registered. Clinically it is manifested in typical weight loss among pigs aged 8-18 weeks. Muscle atrophy, cardiomyopathy and pulmonary pathology leads to choke, anemia, pale mucous membranes. Sometimes there is jaundice and sporadic diarrhea. Inguinal lymph nodes are enlarged. As a result of the temperature low-grade animals are sup- 
pressed. The mortality rate among infected pigs PCV2$\mathrm{SD}$ ranges from $5-50 \%$. Body weights gain is less than normal, becoming ready for being sold increases (Allan and Ellis, 2000). Three times increased in lymph nodes, thymus atrophy, infarction of the spleen, diffuse edema of the lungs, liver jaundice, enlarged kidneys with areas of infiltration of lymphocytes, stomach ulcers, multifocal myocarditis are recorded during the autopsy. Almost in all organs infiltration of lymphocytes is detected.

The course PCVD in the form of subclinical infections (PCV2-SI) is characterized with invisible clinical signs. Low body weight gain amonf animals of feeding group is the only sign. Experts of farms can link it with poor quality food, sanitary conditions of the premises, etc. swine genetics. Typically PCV2-SI is recorded in disadvantaged farms where PCVD affects pigs for years and is never diagnosed.

The course of PCVD in the form of disease of the reproductive system (PCV2-RD) is characterized with abortion in the third trimester of gestation and birth of non-viable offspring. This syndrome is characterized by the absence of other clinical signs in sows. Veterinary experts in this case may suspect brucellosis, leptospirosis, mycoplasmosis, mycotoxicoses, PRRS and swine parvovirus.

The course in the form of PCVD dermatonefro pathology syndrome (PDNS) should also be considered as one of the clinical manifestations of PCVD. PDNS is registered among pigs aged $2-6$ months. Pigs older than 8 months it is almost undetectable. This syndrome refers to the of hypersensitivity type III. Typical for PDNS is acute course with signs of anorexia, depression, hypotension, or $40,5-41^{\circ} \mathrm{C}$ temperature, necrotizing vasculitis. On the skin in the hind limbs and perineum appear erythema, which is then covered with a thin scab and disappear on its own. These symptoms are sometimes confused with signs of acute course of erysipelas.

Respiratory disease complex (PRDC) is considered as a separate syndrome PCVAD. It is a multifactorial disease that affects pigs $12-24$ weeks aged (Gjurovski et al., 2015). It is characterized with fever, cough, nasal leakage, acute pulmonary edema, weight loss. It can be confused with pasteurellosis, haemophilosis pleuropneumonia and other diseases.

The aim of our study was to establish the nature of clinical manifestations in pigs that are suspected to PCVD.

\section{Material and methods}

According the notification of clinical and pathological signs PCVD we examined the number of pigs on the farm that specializes in young animals received and fattening. The farm has reproductive herd. Pigs were kept in suboptimal health conditions (lack of ventilation, high content of ammonia in the air, low temperature in the rooms). Regular diagnostic and preventive measures were not taken. Specialists farms concerned about the low increase in body weight, but they did not think of circovirus infection pigs. We divided all pigs into three groups. The first group - adult sows, the second group - pigs aged 0-28 days, the third group - pigs aged between $35-180$ days.
All animals were clinical examined. For laboratory studies were selected lymph nodes. The material studied in SDC «Bio-test-laboratory».

\section{Results and discussion}

All animals were clinically examined. Animals of the first group did not have clinical signs specific to PCVD. Animals of the second group were characterized with heterogeneity of group, weight of piglets at birth ranged from 0.9 to $1.3 \mathrm{~kg}$. Animals were behind in growth, development, mortality ranged from 10\%. Diarrhea and cough were not detected. The third group of animals was characterized with strong heterogeneity of herds and low growth. Testing revealed a lag in growth and development, depression, pale mucous membranes, increasing the inguinal, submaxillary, retropharyngeal lymph nodes. Autopsy revealed: fibrinous pleuropneumonia, myocarditis, filling with blood of spleen and liver, enlarged kidneys, increased all the lymph nodes, especially inguinal and ripples. Signs of generalized staph infection were recorded with one pig. Using PCR analysis confirmed PCV2.

\section{Conclusions}

1. Circovirus infection of pigs (PCVD) often occurs in association with other infectious agents, characterized by symptoms of various syndromes.

2. Depression, low body weight gain and enlarged lymph nodes are the main clinical signs, which are often registered among pigs aged 35 - 180 days.

3. Given erased clinical signs of circovirus infection for early diagnosis should conduct a systematic survey of pigs by PCR analysis.

4. All sows should be vaccinated against circovirus infection.

\section{References}

Segalés, J, Allan, G.M., Domingo, M. (2005). Porcine circovirus diseases. Anim Health Res Rev. Dec, 6(2), $119-42$.

Opriessnig, T., Langohr, I. (2013). Current state of knowledge on porcine circovirus type 2-associated lesions. Vet Pathol. Jan. 50(1), 23-38.

Kim, J, Ha, Y, Jung, K, et al. (2004). Enteritis associated with porcine circovirus 2 in pigs. Can J Vet Res. 68, 218-221.

Yifei, Yang, Ruihan, Shi, Ruiping, She, Jingjing, Mao, Yue, Zhao, Fang, Du, Can, Liu, Jianchai, Liu, Minheng, Cheng, Rining, Zhu, Wei, Li, Xiaoyang, Wang, Majid, Hussain Soomro (2015). Fatal disease associated with Swine Hepatitis E virus and Porcine circovirus 2 co-infection in four weaned pigs in China. BMC Veterinary Research. 11, 77.

Madson, D., Opriessnig, T. (2011). Effect of porcine circovirus type 2 (PCV2) infection on reproduction: disease, vertical transmission, diagnostics and vaccination. Anim Health Res Rev. 12, 47-65.

Romeo, E, Sanchez, R.E. Jr., Meerts, P., Nauwynck, H.J., Pensaert, M.B. (2003). Change of porcine circovirus 2 
target cells in pigs during development from fetal to early postnatal life. Vet. Microbiol. Aug. 29, 95(1-2), $15-25$.

Ellis, J., Hassard, L., Clark, E., et al. (1998). Isolation of circovirus from lesions of pigs with postweaning multisystemic wasting syndrome. Can Vet J. 39, 44-51.

Quintana, J, Segalés, J, Rosell, C, et al. (2001). Clinical and pathological observations on pigs with postweaning multisystemic wasting syndrome. Vet Rec. 149, $357-361$
Allan, G.M., Ellis, J.A. (2000). Porcine circoviruses: a review. J. Vet Diagn Invest. 12, 3-14.

Gjurovski, Ivica, Angelovski, Branko, Dovenski, Toni, Mitrov, Dine. (2015). Diagnostic Characteristics of Circovirus Infection in Pigs //Macedonian Veterinary Review. 38(1), P. 73-78.

Стаття надійшла до редакиії 25.09.2016 